\title{
Gambaran Anti-Plasmodium sp. Pada Anggota Tentara Nasional Indonesia Angkatan Darat Di Kota Cimahi
}

\author{
Patricia Gita Naully $^{1}$, Gina Khairinisa ${ }^{2}$, Dewi Ratih Saputri ${ }^{3}$ \\ ${ }^{1,2,3}$ Analis Kesehatan, Stikes Jenderal Achmad Yani Cimahi \\ Email: patriciagitanaully@gmail.com
}

\begin{abstract}
Tanggal Submit:

23 Agustus 2018

Tanggal Review:

23 Oktober 2018

Tanggal Publish

Online:

29 November 2018

Malaria is a disease caused by Plasmodium sp. The presence of such parasites in body can be characterized by the presence of anti-Plasmodium sp. antibodies. Malaria cases are still prevalent in Indonesia and generally occur in people who travel to endemic areas. One of the jobs that obliges its members to serve to various regions, including endemic areas is the Indonesian Army (TNI AD). Many Army personnel residing in Cimahi City. The purpose of this study is to determine the overview of malaria in members of the Army in Cimahi City. This study used a sample of $30 \mathrm{TNI}$ AD who are residing in Cimahi City and have been assigned to various regions in Indonesia. Venipucture is only performed on respondents who have signed informed consent and filled out the interview form. Malaria screening is performed using immunochromatography that can detect anti- $P$. vivax and anti- $P$. falciparum antibodies, with a high degree of sensitivity and specificity. Of the 30 people, there were 4 people (13.3\%) who had been infected with malaria and $2(6.7 \%)$ of whom had experienced mixed malaria. All respondents who tested positive for malaria claimed to have been assigned to malaria endemic areas such as Papua and Maluku for several years.
\end{abstract}

Keywords : Immunochromatography, Indonesian Army, Malaria, Plasmodium sp.

\section{PENDAHULUAN}

Malaria adalah salah satu penyakit yang disebabkan oleh parasit. Parasit tersebut terdiri dari Plasmodium vivax, Plasmodium falciparum, Plasmodium malariae, Plasmodium ovale, dan Plasmodium knowlesi (Cowman et al., 2016). Dari kelima spesies tersebut, $P$. vivax dan $P$. falciparum adalah dua spesies yang paling berbahaya. $P$. vivax sering kali menyebabkan kekambuhan beberapa bulan setelah infeksi pertama karena bentuk hypnozoite dari spesies tersebut dapat bertahan lama di dalam hati (Lalloo dan Hill, 2008). $P$. falciparum menjadi penyebab sebagian besar penderita malaria meninggal dunia (Arsin, 2012). Vektor dari Plasmodium sp. adalah nyamuk Anopheles betina (Cowman et al., 2016). 
Orang yang terserang malaria umumnya akan mengalami demam dengan fluktuasi suhu secara teratur, anemia, pembengkakan limpa, dan adanya pigmen dalam jaringan (Arsin, 2012). Infeksi oleh Plasmodium sp. ditandai dengan ditemukannya protein HRP2 (P. falciparum), pLDH (P. vivax), atau antibodi anti-Plasmodium sp. di dalam darah yang terbentuk sebagai respon pertahanan tubuh (Azikiwe et al., 2012). Menurut Cho et al. (2016), antibodi anti-Plasmodium sp. dapat dijadikan penanda malaria khususnya di daerah endemis dimana infeksi ringan dan reinfeksi sering terjadi.

Berdasarkan data World Health Organization (WHO), pada tahun 2016 diperkirakan ada 216 juta orang yang terinfeksi malaria di dunia (WHO, 2017). Angka ini mengalami kenaikan sekitar 5 juta orang dari data tahun 2015. Sebagian besar kasus malaria terjadi di daerah Afrika (90\%) dan Asia Tenggara (7\%). Salah satu negara di Asia Tenggara yang memiliki jumlah kasus malaria terbanyak adalah Indonesia. Pada tahun 2013, Indonesia menduduki posisi kedua setelah Myanmar dengan angka prevalensi malaria sebesar 16\% (Mahmudi dan Yudhastuti, 2015).

Menurut data Kementerian Kesehatan RI (2016), kasus malaria di Indonesia masih terkonsentrasi di wilayah Timur. Dari data tersebut dapat terlihat bahwa ada beberapa daerah di Indonesia yang endemis malaria, antara lain Papua, Nusa Tenggara Timur, Maluku, dan Bengkulu. Walaupun yang termasuk daerah endemis hanya empat daerah tersebut, kasus malaria masih dapat ditemukan di daerah seperti Sulawesi dan Kalimantan. Hal ini berhubungan erat dengan keadaan lingkungan alami yang sangat mendukung dan mempengaruhi penyebaran vektor malaria, seperti iklim, suhu, dan curah hujan (Wirth dan Alonso, 2017).

Salah satu penyebab kasus malaria di Indonesia adalah mobilitas penduduk dari daerah endemis (Arsin, 2012). Hal ini terjadi pula di Swedia (Askling et al., 2005), Inggris (Health Protection Agency, 2008), dan Ameriksa Serikat (Mali et al., 2011). Peningkatan kasus malaria pada ketiga negara tersebut terjadi karena banyaknya penduduk mereka yang berkunjung ke daerah endemis seperti Afrika selama kurun waktu tertentu. Menurut Askling et al. (2005), peningkatan kasus malaria di suatu wilayah dapat disebabkan oleh dua kemungkinan, yaitu banyaknya penduduk yang berpergian ke daerah endemis atau datangnya imigran dari daerah endemis ke wilayah tersebut. Berdasarkan fakta tersebut, maka salah satu pekerjaan yang berpotensi tinggi terserang penyakit malaria dan dapat 
meningkatkan jumlah kasus malaria di Indonesia adalah Tentara Nasional Indonesia (TNI) Angkatan Darat (AD).

TNI AD adalah salah satu cabang angkatan perang di Indonesia. Berdasarkan Peraturan Kasad Nomor Perkasad/125/XII/201, TNI AD memiliki 4 tugas pokok, yaitu melaksanakan Operasi Militer untuk Perang (OMP) dan Operasi Militer Selain Perang (OMSP), menjaga keamanan wilayah perbatasan darat dengan negara lain dan pulau-pulau terluar, membangun dan mengembangkan kekuatan Matra Darat, serta memberdayakan wilayah pertahanan di darat (Lolombulan, 2015).

Seluruh tugas dan tanggung jawab tersebut membuat anggota TNI AD harus bersedia untuk ditugaskan diberbagai daerah di Indonesia, mulai dari daerah perkotaan, perbatasan, hingga pedalaman.

Dengan kata lain, besar kemungkinan anggota TNI AD diberikan tugas untuk mengabdi di daerah endemis malaria seperti yang telah dijabarkan sebelumnya. Namun, masih jarang orang yang mempublikasikan hasil penelitian mereka terkait gambaran penyakit malaria di kalangan TNI AD. Adapun penelitian Mayasari et al. (2015) pernah menyebutkan bahwa prevalensi penyakit malaria

pada

anggota

PNS/TNI/Polri/BUMD sebesar 2\%.

Cimahi merupakan salah satu kota di Indonesia yang paling banyak ditempati oleh anggota TNI AD. Sekitar $60 \%$ wilayah kota Cimahi digunakan oleh tentara (Badan Pusat Statistik Kota Cimahi, 2015). Hal ini terbukti dengan banyaknya fasilitas, pusat pendidikan, dan markas militer yang didirikan di kota tersebut. Kondisi anggota TNI AD di Kota Cimahi dianggap dapat mewakili kondisi anggota TNI AD di daerah lain. Maka dari itu, penelitian ini bertujuan untuk mengetahui gambaran anti-Plasmodium sp. pada anggota TNI AD di Kota Cimahi.

\section{METODE PENELITIAN}

\section{Pernyataan Etik}

Penelitian ini sudah mendapatkan perizinan etik dari Komisi Etik Penelitian Kesehatan Stikes Jenderal Achmad Yani. Semua responden telah mengetahui tujuan, manfaat, dan prosedur penelitian serta menandatangani informed consent sebagai tanda kebersediaan mereka untuk ikut serta dalam penelitian ini.

\section{Sampel Penelitian}

Sampel yang digunakan dalam penelitian ini adalah 30 orang anggota TNI AD yang bekerja di Pusat Pendidikan Peralatan (Pusdikpal). Kriteria sampel yang digunakan antara 
lain harus berdomisili di Kota Cimahi dan sudah pernah ditugaskan ke berbagai daerah di Indonesia. Seluruh sampel telah mengisi formulir wawancara yang berisikan pertanyaan tentang identitas, daerah penugasan, lama bertugas di masing-masing daerah, serta penggunaan obat preventif malaria.

\section{Pengambilan dan Pengolahan}

\section{Spesimen}

Pengambilan spesimen berupa darah vena dilakukan menggunakan tabung vakum berwarna merah yang tidak mengandung antikoagulan. Tabung tersebut disentrifugasi dengan kecepatan $3000 \mathrm{rpm}$ selama 15 menit untuk mendapatkan serum.

\section{Pemeriksaan Malaria}

Pemeriksaan malaria dilakukan menggunakan imunokromatografi yang dapat mendeteksi keberadaan antibodi anti- $P$. vivax dan anti- $P$. falciparum dalam tubuh. Imunokromatografi tersebut memiliki sensitivitas terhadap anti- $P$. vivax sebesar $86 \%$ dan anti- $P$. falciparum sebesar $\quad 87 \%$ serta spesifisitas sebesar 99,5\%. Hasil positif ditandai dengan terbentuknya dua buah garis berwarna merah pada daerah kontrol (C) dan daerah tes (T). Garis berwarna yang muncul pada daerah Tes 1 (T1) menandakan adanya anti- $P$. falciparum sedangkan garis yang muncul pada daerah Tes 2 (T2) menandakan adanya anti-P. vivax.

\section{Pengolahan dan Analisis Data}

Data yang didapatkan berupa hasil wawancara dan pemeriksaan laboratorium. Kedua data tersebut diolah dan dianalisis dengan teknik analisis deskriptif.

\section{HASIL PENELITIAN}

Seluruh sampel dalam penelitian ini adalah laki-laki yang berusia antara 25 - 57 tahun. Tidak adanya sampel perempuan disebabkan mayoritas anggota TNI AD yang bekerja di Pusdikpal dan memenuhi kriteria sampel adalah laki-laki. Sampel penelitian berasal dari berbagai bidang kerja, mulai dari staff $(26,7 \%)$ hingga anggota TNI AD yang bekerja di lapangan (20\%) (Tabel 1).

Daerah penugasan sampel cukup menyebar dari wilayah barat seperti Aceh sampai wilayah timur seperti Papua. Masa penugasan mereka pun beragam, ada yang 3 tahun, 5 tahun, bahkan sampai 12 tahun. Dari data wawancara, hampir semua responden (90\%) mengaku pernah mengonsumsi obat preventif.

Berdasarkan hasil pemeriksaan laboratorium, didapatkan hasil positif malaria pada 4 orang $(13,3 \%)$ anggota TNI AD. 
Tabel 1. Karakteristik Sampel Penelitian dan Hasil Pemeriksaan Malaria

\begin{tabular}{|c|c|c|c|c|}
\hline \multirow[b]{2}{*}{ Variabel } & \multicolumn{2}{|c|}{ Total } & \multicolumn{2}{|c|}{ Positif Malaria } \\
\hline & $\mathbf{N}$ & $\%$ & $\begin{array}{c}\text { P. falciparum } \\
\text { N }(\%)\end{array}$ & $\begin{array}{c}P \text {. falciparum }+P \text {. vivax } \\
\mathrm{N}(\%)\end{array}$ \\
\hline Total Subjek & 30 & 100 & $2(6,7)$ & $2(6,7)$ \\
\hline \multicolumn{5}{|l|}{ Umur (Tahun) } \\
\hline $25-35$ & 3 & 10 & 0 & 0 \\
\hline $36-46$ & 13 & 43,3 & $2(15,4)$ & $1(7,7)$ \\
\hline $47-57$ & 14 & 46,7 & 0 & $1(7,1)$ \\
\hline \multicolumn{5}{|l|}{ Bidang Kerja } \\
\hline Staff & 8 & 26,7 & 0 & 0 \\
\hline Departemen Senjata & 4 & 13,3 & 0 & 0 \\
\hline Departemen Teknik Mekarika & 4 & 13,3 & 0 & 0 \\
\hline Departemen Kendaraan & 4 & 13,3 & 0 & 0 \\
\hline Departemen Munisi & 4 & 13,3 & 0 & 0 \\
\hline Lapangan & 6 & 20 & $2(33,3)$ & $2(33,3)$ \\
\hline \multicolumn{5}{|l|}{ Daerah Penugasan } \\
\hline Aceh & 2 & 6,7 & $1(50)$ & 0 \\
\hline Sumatera & 3 & 10 & 0 & 0 \\
\hline Jawa Barat & 1 & 3,3 & 0 & 0 \\
\hline Kalimantan & 6 & 20 & 0 & 0 \\
\hline Sulawesi & 3 & 10 & $1(33,3)$ & 0 \\
\hline Timor-Timur & 3 & 10 & 0 & 0 \\
\hline Maluku & 4 & 13,3 & 0 & $1(25)$ \\
\hline Papua & 8 & 26,7 & 0 & $1(12,5)$ \\
\hline \multicolumn{5}{|l|}{ Lama Penugasan(Tahum) } \\
\hline $0-5$ & 5 & 16,7 & 0 & 0 \\
\hline $6-10$ & 18 & 60 & $2(11,1)$ & $2(11,1)$ \\
\hline $10-15$ & 7 & 23,3 & 0 & 0 \\
\hline \multicolumn{5}{|l|}{ Obat Preventif } \\
\hline $\mathrm{Ya}$ & 27 & 90 & 0 & $1(3,7)$ \\
\hline Tidak & 3 & 10 & $2(66,7)$ & $1(33,3)$ \\
\hline
\end{tabular}

Pada spesimen berupa serum dari seorang saja yang pernah mengalami keempat orang tersebut berhasil ditemukan adanya antibodi antirelaps atau kambuh.

Seluruh responden yang pernah Plasmodium sp. Dua orang pernah terinfeksi oleh $P$. falciparum dan 2 orang lagi pernah mengalami infeksi campuran yaitu oleh $P$. falciparum dan $P$. vivax. Ketika diwawancara lebih lanjut, keempat orang tersebut pernah mengalami gejala klinis malaria dan melakukan pemeriksaan menggunakan metode mikroskopik. Dari 2 orang yang mengalami infeksi campuran, hanya 


\section{PEMBAHASAN}

Dari 30 orang anggota TNI AD di Kota Cimahi, terdapat 4 orang yang pernah terserang penyakit malaria. Hal itu terbukti melalui pemeriksaan antibodi anti-Plasmodium sp. menggunakan imunokromatografi. Deteksi penyakit malaria umumnya dilakukan dengan metode mikroskopis, yaitu pemeriksaan preparat darah tebal dan tipis (Azikiwe et al., 2012). Namun, sekarang telah berkembang beberapa metode baru untuk mendiagnosis penyakit tersebut, salah satunya adalah imunokromatografi atau yang sering disebut Rapid Diagnostic Test (Cho et al., 2016).

Beberapa penelitian telah membuktikan bahwa metode tersebut jauh lebih sensitif dan spesifik dibandingkan metode konvensional (Stauffer et al., 2009; Batwala et al., 2010; Azikiwe et al., 2012). Pemeriksaan imunokromatografi untuk malaria terdiri dari pemeriksaan antigen dan antibodi. Menurut Cho et al. (2016), pemeriksaan antibodi anti-Plasmodium sp. dapat mendeteksi infeksi walaupun jumlah parasit dalam tubuh sedikit.

Jenis anti-Plasmodium yang terdeteksi pada penelitian ini adalah anti- $P$. falciparum dan anti- $P$. vivax. Jumlah orang yang terinfeksi $P$. falciparum lebih banyak dari pada $P$. vivax. Hal tersebut sesuai dengan Arsin
(2012) yang menyatakan bahwa jenis plasmodium yang dominan di Indonesia adalah $P$. falciparum lalu diikuti oleh $P$. vivax. $P$. falciparum banyak ditemukan di daerah tropis yang memiliki iklim panas dan kelembapan yang tinggi sedangkan $P$. vivax lebih banyak ditemukan di daerah yang beriklim dingin, namun dapat juga ditemukan di daerah subtropis dan tropis (Wirth dan Alonso, 2017). Jenis plasmodium yang lain juga pernah ditemukan di Indonesia, namun hanya pada daerah tertentu saja.

Berdasarkan hasil wawancara lebih lanjut, diketahui bahwa dari 2 orang anggota TNI AD yang mengalami infeksi campuran hanya 1 orang yang pernah mengalami kekambuhan. Kekambuhan malaria umumnya terjadi pada orang yang terinfeksi oleh $P$. vivax karena kemampuan parasit tersebut bertahan lama di dalam hati (Lalloo dan Hill, 2008). Ternyata kekambuhan tidak selalu terjadi pada orang yang terinfeksi spesies tersebut. Mading dan Yunarko (2014) menyatakan bahwa selain karena bentuk hypnozoite dari parasit, kekambuhan pada malaria dapat terjadi karena rendahnya titer antibodi atau peningkatan kemampuan parasit melawan antibodi tersebut.

Dari hasil pemeriksaan laboratorium dan wawancara (Tabel 1), terlihat bahwa TNI AD yang bekerja di bagian lapangan lebih beresiko 
terjangkit malaria dibandingkan dengan

staff atau anggota departemen lain. Hasil ini serupa dengan beberapa penelitian lain yang membuktikan bahwa pekerjaan yang banyak menghabiskan waktu di luar ruangan seperti petani, pekerja hutan, dan berladang memiliki resiko lebih tinggi dibandingkan pekerjaan yang lain (Falah dan Meiliasari, 2014; Pratamawati dan Widiarti, 2015). Pekerjaan tersebut memiliki probabilitas tinggi terinfeksi Plasmodium sp. melalui gigitan nyamuk di luar ruangan.

Bila ditinjau dari daerah penugasannya, dua orang yang terinfeksi P. falciparum pernah bertugas di Aceh dan Sulawesi sedangkan dua orang yang mengalami infeksi campuran pernah bertugas di Papua dan Maluku (Tabel 1). Hasil ini sejalan dengan data Kementerian Kesehatan RI (2016) yang melaporkan bahwa Papua merupakan daerah yang paling endemis malaria dengan angka Annual Parasite Incidence (API) sebesar 31,93 dan diikuti oleh daerah Maluku dengan API sebesar 5,81. Beberapa penelitian juga melaporkan bahwa di Papua sering kali ditemukan infeksi oleh $P$. vivax (Karyana et al., 2008; Tjitra et al., 2008; Kho et al., 2018) bahkan banyak juga terjadi infeksi campuran baik antara $P$. falciparum dengan $P$. vivax atau $P$. falciparum dengan $P$. malariae
(Karyana et al., 2008; Tjitra et al., 2008).

Suatu daerah dapat menjadi endemis malaria disebabkan banyaknya jumlah vektor di daerah tersebut. Jumlah vektor dan perkembangan parasit dalam vektor sangat dipengaruhi oleh kondisi lingkungan seperti suhu, kelembapan udara, curah hujan, topografi, sinar matahari, dan angin (Wirth dan Alonso, 2017). Selain itu, segala unsur flora dan fauna di lingkungan sekitar juga dapat mempengaruhi hal tersebut. Umumnya Plasmodium sp. dapat berkembang dalam tubuh nyamuk secara optimum pada suhu 20-30oC, kelembapan minimal $60 \%$, dan pada daerah dengan ketinggian maksimal 2000 meter diatas permukaan laut (Arsin, 2012).

Selain daerah penugasan, nampak adanya pengaruh lama penugasan terhadap penyakit malaria. Responden yang terinfeksi Plasmodium sp. adalah mereka yang menjalankan tugas di daerah endemis selama kurun waktu 610 tahun. Jangka waktu tersebut termasuk jangka waktu yang cukup lama. Hal ini jelas memperbesar kemungkinan anggota TNI AD tersebut terserang malaria. Dalam penelitiannya, Leder et al. (2004) membuktikan bahwa semakin lama pelancong (traveler) bermukim di daerah endemis maka semakin besar pula kemungkinan orang 
tersebut terpapar gigitan vektor

Plasmodium sp.

Penyakit malaria sebenarnya dapat dicegah dengan obat anti malaria seperti klorokuin dan sulfadoksinpirimethamin (Kementerian Kesehatan RI, 2013). Menurut Baird (2005), kebanyakan obat anti malaria dapat membunuh parasit ketika mereka berada di dalam sel darah merah. Data penelitian menunjukkan bahwa 3 dari 4 orang TNI AD yang terinfeksi tidak pernah mengonsumsi obat tersebut, namun ada 1 orang yang mengonsumsi obat tersebut (Tabel 1).

Kasus malaria pada orang yang sudah mengonsumsi obat anti malaria banyak dilaporkan pada beberapa penelitian (Karyana et al., 2008; Tjitra et al., 2008). Kasus ini terjadi karena adanya Plasmodium sp. khususnya $P$. falciparum yang Multidrug Resistant (MDR) yaitu kondisi dimana Plasmodium sp. resisten terhadap beberapa jenis obat anti malaria (Wirth dan Alonso, 2017). MDR dapat disebabkan oleh beberapa hal, antara lain mutasi pada gen-gen Plasmodium sp., dosis obat, kurangnya kepatuhan individu dalam mengonsumsi obat, dan faktor transmisi malaria yang meliputi intensitas, drug pressure, respon imun inang (Simamora dan Fitri, 2007). Untuk mengatasi hal tersebut, Kementerian Kesehatan RI (2013) menyarankan untuk mengonsumsi kombinasi turunan artemisinin dengan obat anti malaria lain yang biasa disebut dengan Artemisinin based Combination Therapy (ACT).

Selain obat anti malaria, infeksi oleh Plasmodium sp. dapat dicegah dengan berbagai macam cara. Menurut Pratamawati dan Widiarti (2015), pengetahuan merupakan kunci paling penting untuk mencegah infeksi tersebut. Pengetahuan yang dimiliki oleh seseorang akan berpengaruh terhadap sikap dan tindakannya terhadap suatu penyakit. Tindakan seperti penggunaan obat anti nyamuk (Santy et al., 2014), penggunaan kelambu (Erdinal et al., 2006; Sir et al., 2015), dan penggunaan celana panjang serta baju berlengan panjang ketika melakukan kegiatan pada malam hari (Sunarsih et al., 2009; Falah dan Meiliasari, 2014) dapat mencegah gigitan vektor malaria.

\section{SIMPULAN DAN SARAN}

\section{Simpulan}

Berdasarkan hasil wawancara dan pemeriksaan laboratorium dari 30 orang anggota TNI AD yang berdomisili di Kota Cimahi, terdapat 4 orang $(13,3 \%)$ yang pernah terjangkit penyakit malaria. Dua orang $(6,7 \%)$ terinfeksi $P$. falciparum dan 2 orang (6,7\%) lagi mengalami penyakit malaria campuran. 
Saran

Hasil penelitian ini sebaiknya ditindaklanjuti dengan pelaksanaan kegiatan edukasi atau penyuluhan tentang malaria kepada anggota TNI AD yang akan ditugaskan ke berbagai daerah di Indonesia sebagai upaya preventif penyakit tersebut.

\section{DAFTAR PUSTAKA}

Arsin, A.A. 2012. Malaria di Indonesia tinjauan aspek epidemiologi. Makasar. Masagena Press.

Askling, H.H., Nilsson, J., Tegnell, A., Janzon, R., Ekdahl, K. 2005. Malaria Risk in Travelers. Emerging Infectious Diseases. 11(3): 436-441.

Azikiwe, C.C.A., Ifezulike, C.C., Siminialayi, I.M., Amazu, L.U., Enye, J.C., Nwakwunite, O.E. A. 2012. A Comparative Laboratory Diagnosis of Malaria: Microscopy Versus Rapid Diagnostic Test Kits. Asian Pac J Trop Biomed. 2(4): 307-310.

Badan Pusat Statistik. 2015. Cimahi Selatan dalam Angka 2015. Cimahi. Badan Pusat Statistik.

Baird, J.K. 2005. Effectiveness of Antimalarial Drugs. $N$ Engl $J$ Med. 352:1565-1577.

Batwala, V., Magnussen, P., Nuwaha, F. 2010. Are Rapid Diagnostic Tests More Accurate in Diagnosis of Plasmodium falciparum Malaria Compared to Microscopy at Rural Health Centres?. Malaria Journal. 9: 349 .
Cho, S.J., Lee, J., Lee, H.J., Jo, H.Y., Sinniah, M., Kim, H.Y., Chong, C.K., Sng, H.O. 2016. A Novel Malaria $\mathrm{Pf} / \mathrm{Pv} \quad \mathrm{Ab}$ Rapid Diagnostic Test Using a Differential Diagnostic Marker Identified by Network Biology. Int. J. Biol. Sci. 12(7): 824-835.

Cowman, AF., Healer, J., Marapana, D., Marsh, K. 2016. Malaria: Biology and Disease. Cell. 167: 610-624.

Erdinal., Susanna, D., Wulandari, R.A. 2006. Faktor-Faktor yang Berhubungan dengan Kejadian Malaria di Kecamatan Kampar Kiri Tengah, Kabupaten Kampar. Jurnal Makara Kesehatan. 10(2): 64-70.

Falah, W. dan Meiliasari, F. 2014. Hubungan Faktor Pekerjaan dan Lingkungan dengan Kejadian Malaria di Kecamatan Jaro Kabupaten Tabalong. An Nadaa. 1(1): 21-25.

Health Protection Agency. 2008. Malaria Imported into the UK in 2007: Implications for those Advising Travellers. Health Protection Report. 2(17): 1-14.

Karyana, M., Burdarm, L., Yeung, S., Kenangalem, E., Wariker, N., Maristela, R., Umana, K.G., Vemuri, R., Okoseray, M.J., Penttinen, P.M., Ebsworth, P., Sugiarto, P., Anstey, N.M., Tjitra, E., Price, R.N. 2008. Malaria Morbidity in Papua Indonesia, an Area with Multidrug Resistant Plasmodium vivax and Plasmodium falciparum. Malarian Journal. 7: 148. 
Kementerian Kesehatan RI. 2013. Peraturan Menteri Kesehatan Republik Indonesia Nomor 5 Tahun 2013 tentang Pedoman Tata Laksana Malaria. Jakarta. ementerian Kesehatan RI.

Kementerian Kesehatan RI. 2016. Malaria. Jakarta. Kementerian Kesehatan RI.

Kho, S., Andries, B., Poespoprodjo, J.R., Commons, R.J., Shanti, P.A.I., Kenangalem, E., Douglas, N.M., Simpson, J.A., Sugiarto, P., Anstey, N.M., Price, R.N. 2018. High Risk of Plasmodium vivax Malaria Following Splenectomy in Papua, Indonesia. Clinical Infectious Diseases. 20(20): 1-10.

Lalloo, D.G. dan Hill, D.R. 2008. Preventing Malaria in Travellers. BMJ. 336: 1362-1366.

Leder, K., Black, J., Brien, D.O., Greenwood, Z., Kain, K.C., Schwartz, E., Brown, G., Torresi, J. 2004. Malaria in Travelers: A Review of the GeoSentinel Surveillance Network. Clinical Infectious Diseases. 39: 11041112.

Lolombulan, H.I. 2015. Kajian Yuridis Undang-Undang Nomor 34 Tahun 2004 Tentang Tentara Nasional Indonesia Terhadap Kedudukan dan Tugas TNI dalam Pemberantasan Terorisme di Indonesia. Lex et Societatis. 3(1): 92-100.

Mading, M. dan Yunarko, R., 2014. Respon Imun terhadap Parasit Malaria. Jurnal Vektor Penyakit. 8(2): 45-52.
Mahmudi, M. dan Yudhastuti, R. 2015. Pola Pencarian Pengobatan Klinis Malaria Impor pada

Pekerja Migran. Jurnal Berkala Epidemiologi. 3(2): 230-241.

Mali, S., Tan, K.R, Arguin, P.M. 2011. Malaria surveillance-United States, 2009. MMWR Surveill Summ. 60(3):1-15.

Mayasari, R., Andriayani, D., Sitorus, H. 2015. Faktor Risiko yang Berhubungan dengan Kejadian Malaria di Indonesia (Analisis Lanjut Riskesdas 2013). Buletin Penelitian Kesehatan. 14(1): 1324.

Pratamawita, D.A. dan Widiarti. 2015. Gambaran Lingkungan dan Hubungan Pengetahuan, Sikap dengan Perilaku pada Peningkatan Kasus Malaria di Desa Kalirejo Kecamatan Kokap Kabupaten Kulonprogo Tahun 2012. Vektora. 7(1): 39-48.

Santy., Fitriangga, A., Natalia, D. 2014. Hubungan Faktor Individu dan Lingkungan dengan Kejadian Malaria di Desa Sungai Ayak 3 Kecamatan Belitang Hilir Kabupaten Sekadau. Jurnal Kedokteran Indonesia. 2(1): 265272.

Simamora, D dan Fitri, L.E. 2007. Resistensi Obat Malaria: Mekanisme dan Peran Obat Kombinasi Obat Antimalaria untuk Mencegah. Jurnal Kedokteran Brawijaya. 23(2): 8291.

Sir, O., Arsin, A., Syam, I., Despitasari, M. 2015. Factors Related to Malaria in Kabola Village, Alor District, East Nusa Tenggara Province, 2014. Jurnal Ekologi Kesehatan. 14(4): 334-341. 
Stauffer, W.M., Cartwriht, C.P., Olson, D.A., Juni, B.A., Taylor, C.M., Bowers, S.H., Hanson, K.L., Rosenblatt, J.E., Boulware, D.R. 2009. Diagnostic Performance of Rapid Diagnostic Tests versus Blood Smears for Malaria in US

Clinical Practice. Clinical Infectious Diseases. 49: 908-913.

Sunarsih, E., Nurjazuli., Sulistyani. 2009. Faktor Risiko Lingkungan dan Perilaku yang Berkaitan dengan Kejadian Malaria di Pangkalbalam Pangkalpinang. Jurnal Kesehatan Lingkungan Indonesia. 8(1): 1-9.

Tjitra, E., Anstey, N.M., Sugiarto, P., Warikar, N., Kenangalem, E., Karyana, M., Lampah, D.A., Price, R.N. 2008. MultidrugResistant Plasmodium vivax Associated with Severe and Fatal Malaria: A Prospective Study in Papua, Indonesia. PLoS Med. 5(6): 891-899.

WHO. 2017. World Malaria Report 2017. Geneva. World Health Organization.

Wirth, D. dan Alonso, P. 2017. Malaria: Biology in the era of eradication. New York. Cold Spring Harbor Laboratory Press. 